\title{
Status Threat, Social Concerns, and Conservative Media: A Look at White America and the Alt-Right
}

\author{
Deena A. Isom ${ }^{1, *(\mathbb{D}}$, Hunter M. Boehme ${ }^{2}\left(\mathbb{D}\right.$, Toniqua C. Mikell ${ }^{3}$, Stephen Chicoine ${ }^{4}$ and Marion Renner ${ }^{5}$ \\ 1 Department of Criminology \& Criminal Justice and African American Studies Program, University of South \\ Carolina, Columbia, SC 29208, USA \\ 2 Department of Criminal Justice, North Carolina Central University, Durham, NC 27707, USA; \\ hboehme@nccu.edu \\ 3 Department of Crime and Justice Studies, University of Massachusetts Dartmouth, Dartmouth, MA 02747, \\ USA; tmikell@umassd.edu \\ 4 Bridge Humanities Corp Fellow and Department of Sociology, University of South Carolina, Columbia, \\ SC 29208, USA; chicoins@email.sc.edu \\ 5 Department of Criminology \& Criminal Justice, University of South Carolina, Columbia, SC 29208, USA; \\ mrenner@email.sc.edu \\ * Correspondence: isom@mailbox.sc.edu
}

check for updates

Citation: Isom, D.A.; Boehme, H.M.; Mikell, T.C.; Chicoine, S.; Renner, M. Status Threat, Social Concerns, and Conservative Media: A Look at White America and the Alt-Right. Societies 2021, 11, 72. https://doi.org/ $10.3390 /$ soc 11030072

Academic Editor: Gregor Wolbring

Received: 7 May 2021

Accepted: 29 June 2021

Published: 2 July 2021

Publisher's Note: MDPI stays neutral with regard to jurisdictional claims in published maps and institutional affiliations.

Copyright: (c) 2021 by the authors. Licensee MDPI, Basel, Switzerland. This article is an open access article distributed under the terms and conditions of the Creative Commons Attribution (CC BY) license (https:// creativecommons.org/licenses/by/ $4.0 /)$.

\begin{abstract}
Racial and ethnic division is a mainstay of the American social structure, and today these strains are exacerbated by political binaries. Moreover, the media has become increasingly polarized whereby certain media outlets intensify perceived differences between racial and ethnic groups, political alignments, and religious affiliations. Using data from a recent psychological study of the Alt-Right, we assess the associations between perceptions of social issues, feelings of status threat, trust in conservative media, and affiliation with the Alt-Right among White Americans. We find concern over more conservative social issues along with trust in conservative media explain a large portion of the variation in feelings of status threat among White Americans. Furthermore, more conservative social issues plus feeling of status threat significantly increase the odds of Alt-Right affiliation. Most surprisingly, however, trust in conservative media mitigated, instead of amplified, these associations. Implications and calls for future research are discussed.
\end{abstract}

Keywords: status threat; social issues; conservative media; White Americans; extremism

\section{Introduction}

Racial and ethnic division has been a mainstay of the American social structure since the first contact between Indigenous peoples of the Americas and European colonizers. Political tensions, related to racial-ethnic hierarchies involving Whites and enslaved Africans, were the driving force behind the Civil War and have, in some ways, held constant since then. Today these strains are marked and exacerbated by political binaries, most recently peaking during Donald Trump's tenure as President of the United States and the 6 January 2021 insurrection at the U.S. Capitol [1]. Hate crimes against people of Color, Jews, Muslims, and other marginalized groups have significantly increased following Trump's election and spotlight on the political stage [2,3], with many citing his brazen discriminatory rhetoric as the motivation for the increase in such actions [4]. The proliferation of instant information available in the form of smart devices, 24-h news channels, and social media platforms often contribute to the pervasiveness and divisiveness of such tensions [5,6]. Moreover, the media has become increasingly polarized and biased whereby certain media outlets exacerbate perceived differences between racial and ethnic groups, political alignments, religious affiliations, and so forth [7]. Thus, media outlets may contribute to increasing tensions and widening of the gaps between 'us' and 'them' [8]. Using data from a recent psychological study of the Alt-Right [9], we engage in an analysis of the associations between perceptions of social issues, feelings of status threat, trust in conservative media, and affiliation with 
the Alt-Right among White Americans. Prior to our analysis, we begin with a review of the literature around why many White Americans may be enticed by more conservative media agendas and extremist beliefs.

\section{Longing for "Greater" Days}

At the time of authorship, the recent deaths of George Floyd, Breonna Taylor, and Ahmaud Arbery had reinvigorated social justice uprisings, with \#BlackLivesMatter becoming increasingly mainstream, particularly among corporate entities [10]. This movement called on public and private companies, colleges and universities, and all levels of governments to publicly decry racial injustices, change operating procedures and policies, disavow colonizers' names on buildings, and remove monuments dedicated to the memory of known racists and imperialist figures [11]. These protests magnified the polarization of the current social and political climate, particularly via white supremacists' and extremists' presence, seen nationally at these events [12]. Recent research has emerged focusing on right-leaning political ideologies in order to better understand the roots of such perspectives.

For instance, Hochschild [13] and Wuthnow [14] qualitatively examine various cities throughout rural (White) America ('Rural' is defined as geographic areas consisting of low population numbers, agricultural driven economy that supply's much of America's food, water, energy, and other natural resource production [15]. 'Rural' may be considered synonymous with White given most rural communities are majority White (typically upwards of $90 \%)$ ). Wuthnow [14] suggests such towns tend to establish 'moral communities,' in which morals are largely influenced by Christian values. Such communities function within an 'us vs. them' culture, in which misogyny and racism are firmly entrenched in the community and progressive concerns such as pro-choice policies, LGBTQ+ rights, and shifts in racial/ethnic demographics are largely stigmatized. Members of these moral communities may feel fear and anger when they perceive that their way of life is threatened by the government's inability to protect their economic and social interests. Relatedly, Hochschild [13] reveals that the cultural fabric nested within a Louisiana community greatly influences community members' political ideologies. Taxes, religion, and pride represent key factors in citizens' choice to vote Republican, despite such political beliefs being out of line with their economic interests. Hochschild [13] notes that in a town consisting of mostly Whites, its citizens believe that the government is willing to go out of its way to support women, immigrants, and people of Color in obtaining the American Dream, but not themselves. Moreover, both Hochschild [13] and Wuthnow [14] point out that these citizens yearn for the 'good old' days when Whites were better protected.

Such works, along with others [16-22], align with the emerging literature attempting to understand the recent conservative movement uprising, particularly among White Americans, and the election of Donald Trump. For instance, scholars find that Donald Trump's campaign promise to 'Make American Great Again' and return America to the Christian, conservative values it (supposedly) once held significantly aided in his election and particularly appealed to White America [23,24]. Furthermore, adversarial trepidations around social issues such as reproductive rights [25], LBGTQ+ rights [26], immigration [27], and healthcare [28] were, and continue to be, key concerns of Trump's electorate.

These sentiments, however, are not solely a Trump effect. Instead, Trump's rhetoric and actions are symptoms of the White dominance and superiority embedded in America's founding and social institutions. Throughout history, discriminatory ideologies have been endemic to American society-from Black Codes and Jim Crow laws, to the rise of the $\mathrm{Ku} \mathrm{Klux} \mathrm{Klan,} \mathrm{and} \mathrm{still} \mathrm{today} \mathrm{with} \mathrm{the} \mathrm{prevalence} \mathrm{of} \mathrm{mass} \mathrm{incarceration} \mathrm{and} \mathrm{police}$ brutality [5,29-31]. Thus, although some strides toward equity for marginalized others have been made, racial hierarchical structures and whiteness protection programs still prevail in America [5,31]. Yet, the social, economic, and political shifts that threaten white supremacy have left many White Americans longing to 'make America great again' when marginalized voices were successfully silenced and white supremacist ideologies were safe from criticism $[20,31]$. 


\section{What Threatens White America?}

Theories and research on racial threat and status provide insight into White Americans' perceived threat to their majority status position. Substantial social psychological and sociological literature suggests people are motivated to establish and uphold their relative status through social comparisons [32,33], in turn establishing and reinforcing their identity and self-worth [34,35]. Moreover, beyond individuals holding intergroup biases [36], racial threat theory argues that as the racial minority population expands, the racial majority (i.e., Whites) use their political power and influence to increase state sanctioned control over minority groups [37]. Overall, this literature generally purports that as Whites perceive threats to their dominant status position through challenges to their power and privilegewhether politically, economically, or pure numbers-they tend to respond to such believed challenges with increased social control of marginalized others [37-40], greater conservative ideological affiliation and political partisan divides [22,37,41], as well as increased implicit and explicit biases [22,33]. Research finds Whites' perceptions of racial threat are associated with increased police size and expenditures [42,43], more arrests of people of Color [44,45], higher incarceration rates of marginalized populations [46,47], disproportionate sentencing outcomes for people of Color [48,49], more racial stereotyping and higher fear of crime [50,51], as well as increased perceptions of ethnic/immigrant threat $[52,53]$. Scholars also find believed advances of marginalized groups socially, economically, or politically pushes many White Americans toward more extremist conservative groups and support of discriminatory policies [22,54]. Even more, these feelings of status threat increase a sense of solidarity amongst the dominant group (i.e., Whites), thus hardening hostile feelings towards the 'threatening' group [55]. Modern day political media only reinforces these polarities and perceived threats to White America, further fueling the divide [56].

\section{Conservative Media's Grasp}

Research has shown that the media has a substantial impact on the public's consumption of popular culture-including sports team fandom [57], lifestyle and leisure activities [58], fashion trends [59], and other aspects of day-to-day life. Media, however, is particularly powerful in its influence over the way the public engages with politics [60]. Political news, assumed to be true and accurate, reinforces consumers' political ideology and influences their worldview [61]. Thus, the source of political news is integral to the way likely voters interact with society and social institutions. Immediate access and extended exposure to politically biased media outlets strengthens polarized beliefs of viewers [62]. In today's environment with the advancement of technology, the ubiquity of the internet, and the influence of social media, people are inundated with information now more than ever from multiple sources at once [63]. Research consistently demonstrates the influence these types of media have on politics, political affiliation, ideological polarization, and news sensationalization $[62,64,65]$. And, one of the most culpable outlets of such divisive rhetoric is Fox News.

Fox News, well-known for its conservative-leaning political coverage, premiered in 1996 as an around-the-clock news outlet [66]. Not long after Fox News' inception, it established itself as different from the mainstream media's affinity for leftist politicians and the liberal media $[67,68]$. Fox News appeals to conservatives because it presents a patriotic, pro-America persona that is attractive to right-leaning viewers [69]. Viewers of Fox News are exposed to vastly different news than viewers of other outlets, such as CNN or MSNBC, thus leading to an increasingly divisive, polarized political and social environment. Furthermore, Donald Trump is a frequent guest and supporter of Fox News and its anchors [70,71], even appointing former Fox News personalities to his administration [72] and drawing Fox News into his campaign against 'fake news' [73].

Deliberately presented factually incorrect news stories, recently coined as 'fake news,' is not a new phenomenon as fake news has been occurring since humans were able to inscribe writings on clay slabs [74]. Fake news, and the related 'alternative facts,' was 
most recently popularized by Donald Trump during his 2016 presidential run. Donald Trump, verbally and virtually, labels news stories that do not match his rhetoric as 'fake news'. In reality, most news stories he deems as fake news are factual and it is his narrative that is perpetually false [75]. Ironically, Trump's campaign rested on criticizing fake news; though, research finds that the proliferation of fake news during the 2016 campaign proved to be a significant contributor to his presidential election $[64,76]$ and, arguably, his continued communication of alternative facts has helped to maintain his popularity among conservative voters.

Similarly, the Alt-Right, "a set of far-right ideologies, groups, and individuals whose core belief is that 'white identity' is under attack by multicultural forces using 'political correctness' and 'social justice' to undermine white people and 'their' civilization" [77], relies heavily on conspiracy theories that stem from fake news while simultaneously proliferating fake news stories to gain followers and dispel their beliefs, perpetuated largely by the internet and social media [76,78,79]. In fact, the term 'alternative right' was coined by Richard Spencer in 2008 who established a multitude of online and social media forums (including the website alternativeright.com accessed on 1 October 2020) to unite far-right followers and promote extremist ideologies [80]. Coincidently, the Alt-Right has been attributed to aiding the election of Donald Trump through its online and social media presence [6,81]. Even more, the Alt-Right continues to bridge far-right and discriminatory beliefs regarding race, gender, sexual orientation, and so forth into normalized rhetoric seen within American media outlets, including Fox News [80].

The conservative media reach by Fox News, and others such as The Hill and Red State, as well as the continued proliferation of fake news, has perpetuated the development and presence of extremist ideologies, such as the Alt-Right, within normalized media outlets. People self-select certain news outlets, aligning their political beliefs with the political slant of their news organization of choice while ignoring opposing news outlets who offer a different political angle [82]. Furthermore, consistent exposure to slanted political news normalizes the information received [83]. This phenomenon, in turn, intensifies the divisiveness currently seen in the United States [84]. Thus, based on the literature, it seems likely the messaging perpetuated through conservative media (e.g., traditional American [White] way of life is under attack) influences viewers' (primarily White Americans) perceptions of social issues and that such sentiments are associated with feelings of status threat and affiliation with more extremist conservative ideologies.

\section{The Current Study}

Thus, extant research suggests those in dominant status positions (i.e., Whites, and particularly men) are likely to perceive threats to their power and privilege in the wake of social shifts [33,37,38,40,85], often leading to a range of divisive perceptions, beliefs, and behaviors [41,55,86-88]. Furthermore, scholars find the polarization and bias of certain media outlets exacerbates perceived differences between various groups $[7,8,88]$. We integrate and build upon these findings to enhance the understanding of the current rise in animus towards marginalized people brewing in White America. Specifically, we employ a secondary analysis of a recent psychological survey [9] to better bridge the links between feelings of status threat, perceptions of social issues, trust in conservative media, and affiliation with extremist conservative ideologies, particularly the Alt-Right, among White Americans. Our analysis is driven by three research questions:

(1) Are perceptions of social issues associated with status threat for White Americans?

(2) Are perceptions of social issues associated with affiliation with the Alt-Right for White Americans controlling for status threat?

(3) Does trust in conservative media influence these associations? 
Addressing these questions will shed light on the inspirations and pathways to farright, extremist ideologies for White Americans. Unpacking these ideologies and beliefs will help us understand the racial divide in America. Below we discuss the data before presenting our analytical strategy and findings.

\section{Method}

\subsection{Data}

Date were collected by Forscher and Kteily in early 2017. Their original aim was to construct a psychological profile of the Alt-Right. Forscher and Kteily [9] collected two convenience samples through Amazon's Mechanical Turk (MTurk). MTurk is an online survey outlet that provides researchers (or 'requesters') access to a pool of volunteer 'workers' from which to recruit study participants. Requesters may set any constraints or criteria for workers' eligibility to complete the 'task' to better manage the resulting sample. Workers are incentivized for their participation based on the standards established by the requesters (see https:/ /www.mturk.com/product-details accessed on 18 May 2020). Researchers have recognized the superior quality of MTurk samples compared to other convenience samples $[89,90]$ as well as its ability to capture hard-to-reach populations [91], such as the Alt-Right.

Forscher and Kteily's [9] first sample purposefully sought members of the Alt-Right and paid respondents \$3US for their participation. They employed several strategies to ensure those in the Alt-Right sample genuinely identified as such as well as were human respondents and not 'bots'. First, they included probes at the beginning and end of the survey, with the last question urging honesty and ensuring compensation was not response dependent. Additionally, if a respondent answered they did not truly identify with the Alt-Right, they were blocked from participating in either survey for the study. Furthermore, open-ended questions were mined for indicators of participants not genuinely being a part of the Alt-Right (i.e., respondents copying the description of the Alt-Right from Wikipedia or the Southern Poverty Law Center when asked to describe the movement), thus were flagged for exclusion from the analysis. See Forscher and Kteily [9] for a detailed discussion. Thus, despite findings that some MTurk respondents are dishonest to meet study qualifications [92] and politically conservative individuals are often underrepresented on MTurk [93], the original investigators took several steps to ensure those that identified as Alt-Right in the final sample were truly Alt-Right supporters. The comparison sample was collected two weeks later. No specific inclusion criteria were set for the comparison group, and probes were again included throughout the survey to ensure no one in the sample identified with the Alt-Right. Workers were paid \$2US for their participation. Forscher and Kteily [9] deposited their data online (https:/ / osf.io / xge8 q/accessed on 1 May 2020), making it accessible for use in the present study.

For the present study, we merged the Alt-Right and comparison group samples creating a starting sample size of 1491 . Given our focus on White Americans, all selfidentified non-White respondents were eliminated from the initial data pool, cutting the sample size to 1058. The data were then further cut listwise for non-response following the demographic questions (i.e., missing over $70 \%$ of responses) as well as for non-response on central variables of interest (e.g., perceptions of social issues) yielding a final sample of 753 White Americans. Within this sample, missingness of the media items ranged from $0.8 \%$ to $33.7 \%$. We analyzed the sample for systematic or randomly missing data patterns on these items and replaced missing values using multiple imputation. The final sample is composed of 299 White women (39.7\%) and 454 White men.

\subsection{Measures}

\subsubsection{Dependent Variable}

All respondents were asked, "Do you identify with the Alt-Right movement?" ( $1=$ yes). The response serves as an indicator of Alt-Right affiliation. This question appeared at the end of the surveys, which began with a description of the aims of the study (i.e., for the 
Alt-Right subsample: "We're interested in learning more about people who choose to identify with the alt-right movement. We feel that there are a lot of misunderstandings about the alt-right, and that the views of people who identify with the alt-right are not well-represented. We want to address this issue. This is a chance to ensure that your views are represented accurately in the mainstream media or other outlets" [9]). Additionally, the 'Alt-Right' is referred to repeatedly throughout the surveys, including open-ended questions where the participants could describe what they believe the Alt-Right movement is. Thus, while only a single-item indicator, the participants were probed throughout the surveys to understand what was meant by 'Alt-Right'.

\subsubsection{Independent Variables}

Respondents were presented the following prompt: "We're interested in your opinions about what issues you consider to be the biggest problems in the United States. Please read the following issues and rate the extent to which you consider each one an issue for the United States" ( $1=$ not a problem to $7=$ a big problem). Government corruption, Washington elites (i.e., the gap between Washington elites and common folks), the wealth gap (i.e., the gap between the rich and the poor), discrimination against Whites, discrimination against Blacks, political correctness, discrimination against men, discrimination against women, illegal immigration, Islamic terrorism, crime, access to healthcare, and climate change are assessed individually as perceived social issues. Status threat is measured by the mean of nine items such as "If Black Americans were on top, they would want the groups currently dominating to suffer"; and "Whites should lobby to repeal laws that give minorities an advantage on the basis of their race at the expense of Whites" $(1=$ strongly disagree to $7=$ strongly agree $)(\alpha=0.948)$.

\subsubsection{Conditioning Variable}

Respondents were presented the following prompt: “We'd like you to think about your perceptions of outlets for the news. You may view some outlets as trustworthy and some as not trustworthy, or even fake. Please rate the news outlets below as to how trustworthy or untrustworthy you perceive them to be" $(0=$ completely untrustworthy to $100=$ completely trustworthy), and then provided a list of 22 news outlets including $\mathrm{CNN}$, $\mathrm{ABC}$ News, and The Huffington Post. From the list, the mean of the 7 most conservative outlets [94]-Fox News, Breitbart, The Rush Limbaugh Show, The Sean Hannity Show, The Glenn Beck Show, InfoWars, and The Daily Caller-serves as a measure of trust in conservative media.

\subsubsection{Control Variables}

Gender is a dichotomous variable $(1=$ men). Research suggests perceived threats to Whites' social status are associated with more conservative political ideologies [22]. Furthermore, research finds a strong association between support for Donald Trump and affiliation with the Alt-Right [76,95]. Such are controlled for by the question, "Which presidential candidate did you vote for in the 2016 election?" Responses were recoded to $1=$ vote for Trump and $0=$ any other candidate/did not vote. One's financial situation may affect their political and social views [96], thus, respondent's financial situation is controlled for by the question, "How would you describe your own current economic situation-is it very bad, somewhat bad, somewhat good, or very good?" ( 1 = very good to $4=$ very bad, reverse coded from original). Given the significance of peer influence on perceptions [97], we controlled for respondents' having friends in the Alt-Right movement. Respondents were asked to name their five closest friends and then asked, "To what extent does your friend identify as a member of the Alt-Right?" $(1=$ not at all to $7=$ very much) for each friend provided. The mean of the five responses serves as an indicator of friends affiliated with the Alt-Right. Finally, social dominance orientation is defined as one's degree of preference for inequality for perceived lower-status groups [98], and is significantly associated with conservative political affiliation [99] as well as association 
with extremist groups [100]. Social dominance orientation is controlled for by the mean of six items taken from the $\mathrm{SDO}_{7}$ scale [101], (Specific items are: An ideal society requires some groups to be on top and others to be on the bottom; Some groups of people are simply inferior to others; Groups at the bottom are just as deserving as groups at the top (reverse coded); No one group should dominate society (reverse coded); We should work to give all groups an equal chance to succeed (reverse coded); We should do what we can to equalize conditions for different groups (reverse coded) $(1=$ strong disagree to $7=$ strongly agree) $(\alpha=0.922)$. Table 1 presents the descriptive statistics and the correlation matrix for all variables of interest.

\subsection{Analytical Strategy}

We utilized a series of ordinary least squares (OLS) and binary logistic regressions for the present analysis. Standardized coefficients are provided for ease of interpretation. For the OLS regressions, the beta coefficient $(\beta)$ provides the change in the standard deviation of status threat given a one standard deviation increase in the predictor variable with other factors held constant. For the logistic regressions, odds ratios (OR) above one signify greater odds of affiliation with the Alt-Right while results below one indicate lower odds. To assess the conditioning effects, interaction terms were created by taking the product of the variable of interest and trust in conservative media. Variance inflation factors suggest none of the present measures suffer from multicollinearity. Data were cleaned and initial assessments were conducted in SPSS24 and analyses were finalized in Stata15. 
Table 1. Correlation Matrix and Descriptive Statistics.

\begin{tabular}{|c|c|c|c|c|c|c|c|c|c|c|c|c|c|c|c|c|c|c|c|c|c|c|}
\hline & & A & в & $\mathrm{c}$ & $\mathrm{D}$ & $\mathrm{E}$ & $\mathrm{F}$ & G & $\mathrm{H}$ & $\mathrm{I}$ & $\mathrm{J}$ & $\mathrm{K}$ & $\mathrm{L}$ & M & $\mathrm{N}$ & $\mathrm{o}$ & $\mathrm{P}$ & $\mathrm{Q}$ & $\mathrm{R}$ & $\mathrm{s}$ & $\mathrm{T}$ & $\mathrm{U}$ \\
\hline A & Alt-Right Affiliation & 1 & & & & & & & & & & & & & & & & & & & & \\
\hline в & $\begin{array}{l}\text { Government } \\
\text { Corruption }\end{array}$ & -0.113 ** & 1 & & & & & & & & & & & & & & & & & & & \\
\hline c & Washington Elites & $-0.093 *$ & 0.559 ** & 1 & & & & & & & & & & & & & & & & & & \\
\hline D & Wealth Gap & -0.340 ** & 0.301 *** & $0.436^{* *}$ & 1 & & & & & & & & & & & & & & & & & \\
\hline E & $\begin{array}{l}\text { Discrimination } \\
\text { Against Whites }\end{array}$ & $0.519^{* *}$ & 0.019 & 0.020 & -0.268 ** & 1 & & & & & & & & & & & & & & & & \\
\hline F & $\begin{array}{l}\text { Discrimination } \\
\text { Against Blacks } \\
\end{array}$ & $-0.433^{* *}$ & $0.183 * *$ & $0.168^{* *}$ & 0.525 ** & $-0.394 * *$ & 1 & & & & & & & & & & & & & & & \\
\hline G & Political Correctness & 0.375 ** & $0.147^{* *}$ & $0.197^{* *}$ & $-0.181^{* *}$ & $0.517^{* *}$ & -0.295 ** & 1 & & & & & & & & & & & & & & \\
\hline H & $\begin{array}{l}\text { Discrimination } \\
\text { Against Men }\end{array}$ & $0.383^{* *}$ & 0.032 & $0.074^{*}$ & -0.176 ** & $0.666^{* *}$ & $-0.219 * *$ & $0.402^{\text {** }}$ & 1 & & & & & & & & & & & & & \\
\hline I & $\begin{array}{l}\text { Discrimination } \\
\text { Against Women }\end{array}$ & -0.270 ** & $0.112^{* *}$ & 0.129 ** & 0.429 ** & $-0.179 * *$ & $0.665^{* *}$ & -0.244 ** & $-0.185^{* *}$ & 1 & & & & & & & & & & & & \\
\hline $\mathrm{J}$ & Illegal Immigration & $0.481^{* *}$ & 0.033 & 0.008 & -0.336 ** & $0.581^{* *}$ & $-0.437^{* *}$ & 0.551 ** & $0.417^{* *}$ & $-0.267^{* *}$ & 1 & & & & & & & & & & & \\
\hline к & Islamic Terrorism & $0.297 * *$ & $0.080^{*}$ & 0.022 & $-0.208 * *$ & $0.437 * *$ & -0.249 ** & $0.421 * *$ & $0.294^{* *}$ & -0.127 ** & 0.600 ** & 1 & & & & & & & & & & \\
\hline $\mathrm{L}$ & Crime & $0.184^{* *}$ & $0.183^{* *}$ & $0.158^{* *}$ & $-0.074^{*}$ & $0.404^{* *}$ & $-0.136 * *$ & $0.367 * *$ & $0.228 * *$ & 0.010 & $0.502 * *$ & 0.505 ** & 1 & & & & & & & & & \\
\hline M & Access to Healthcare & -0.328 ** & 0.301 ** & $0.262^{* *}$ & $0.562^{* *}$ & $-0.256 * *$ & 0.439 ** & -0.176 ** & $-0.185^{* *}$ & 0.386 ** & $-0.244^{* *}$ & $-0.170^{* * *}$ & -0.017 & 1 & & & & & & & & \\
\hline $\mathrm{N}$ & Climate Change & -0.423 ** & $0.205^{* *}$ & 0.195 ** & $0.547^{* *}$ & $-0.326 *$ & $0.576^{* *}$ & -0.308 ** & $-0.256^{* * *}$ & 0.525 ** & -0.439 ** & $-0.257^{\text {** }}$ & -0.139 ** & $0.502 * *$ & 1 & & & & & & & \\
\hline o & Status Threat & $0.550^{\text {** }}$ & $-0.072^{*}$ & -0.061 & $-0.363 * *$ & $0.701 * *$ & -0.598 ** & $0.473 * *$ & $0.483^{* * *}$ & -0.381 ** & $0.628^{* *}$ & $0.408 * *$ & 0.358 ** & -0.302 ** & -0.422 ** & 1 & & & & & & \\
\hline P & Conservative Media & 0.411 ** & -0.196 ** & -0.114 ** & -0.330 ** & 0.392 ** & -0.353 ** & 0.329 ** & $0.322^{* *}$ & $-0.218^{* *}$ & $0.428^{* *}$ & $0.352^{* *}$ & 0.259 ** & -0.301 ** & $-0.431^{* *}$ & $0.462^{\text {** }}$ & 1 & & & & & \\
\hline $\mathrm{Q}$ & Gender $(\mathrm{Men}=1)$ & 0.141 ** & $-0.085^{*}$ & -0.012 & -0.067 & 0.064 & -0.132 ** & 0.044 & $0.244^{* * *}$ & $-0.211^{* *}$ & 0.012 & -0.044 & -0.120 ** & -0.100 ** & -0.063 & $0.131^{* *}$ & $0.076^{*}$ & 1 & & & & \\
\hline $\mathrm{R}$ & Vote for Trump & 0.529 ** & -0.146 ** & $-0.117^{* *}$ & -0.380 ** & $0.427^{* *}$ & -0.450 ** & 0.358 ** & $0.311^{* * *}$ & $-0.307 * *$ & $0.508^{* *}$ & $0.356^{* *}$ & $0.260^{* *}$ & -0.362 ** & -0.494 ** & $0.479 * *$ & $0.487 * *$ & $0.106^{* *}$ & 1 & & & \\
\hline $\mathrm{s}$ & Financial Situation & $-0.187 * *$ & 0.215 ** & 0.189 ** & 0.273 ** & $-0.124^{* *}$ & 0.150 ** & -0.011 & -0.045 & 0.068 & $-0.107 * *$ & $-0.103^{* * *}$ & $-0.077^{*}$ & $0.232^{* *}$ & 0.124 ** & $-0.138 * *$ & $-0.218 * *$ & -0.037 & $-0.234^{* *}$ & 1 & & \\
\hline T & $\begin{array}{l}\text { Friends Affiliated with } \\
\text { the Alt-Right }\end{array}$ & $-0.214 * *$ & -0.029 & -0.068 & 0.050 & -0.008 & $0.127^{* *}$ & -0.132 ** & -0.023 & 0.141 ** & -0.111 ** & -0.045 & -0.008 & 0.067 & $0.092 *$ & $-0.078^{*}$ & -0.066 & -0.121 ** & -0.087 * & -0.152 ** & 1 & \\
\hline $\mathrm{u}$ & $\begin{array}{l}\text { Social Dominance } \\
\text { Orientation }\end{array}$ & $0.503^{* *}$ & -0.212 ** & -0.239 ** & -0.533 ** & 0.565 ** & -0.601 ** & 0.332 ** & $0.399 * *$ & $-0.386 * *$ & $0.511^{* *}$ & 0.325 ** & 0.248 ** & -0.428 ** & $-0.526 * *$ & 0.680 ** & 0.388 ** & $0.114^{* *}$ & $0.463^{* *}$ & $-0.179 * *$ & $-0.086 *$ & 1 \\
\hline & $\begin{array}{c}\text { Mean } \\
\text { Standard Deviation } \\
\text { Minimum } \\
\text { Maximum }\end{array}$ & $\begin{array}{l}0.58 \\
.49 \\
0 \\
1\end{array}$ & $\begin{array}{c}5.50 \\
1.53 \\
1 \\
7\end{array}$ & $\begin{array}{c}5.29 \\
1.72 \\
1 \\
7\end{array}$ & $\begin{array}{l}4.95 \\
1.94 \\
1 \\
7\end{array}$ & $\begin{array}{l}3.71 \\
2.08 \\
1 \\
7\end{array}$ & $\begin{array}{c}3.89 \\
1.92 \\
1 \\
7\end{array}$ & $\begin{array}{l}4.81 \\
2.00 \\
1 \\
7\end{array}$ & $\begin{array}{c}3.19 \\
1.97 \\
1 \\
7\end{array}$ & $\begin{array}{c}3.84 \\
1.82 \\
1 \\
7\end{array}$ & $\begin{array}{c}4.95 \\
1.90 \\
1 \\
7\end{array}$ & $\begin{array}{c}5.21 \\
1.77 \\
1 \\
7\end{array}$ & $\begin{array}{l}5.01 \\
1.55 \\
1 \\
7\end{array}$ & $\begin{array}{c}5.06 \\
1.77 \\
1 \\
7\end{array}$ & $\begin{array}{l}4.39 \\
2.14 \\
1 \\
7\end{array}$ & $\begin{array}{c}4.23 \\
1.74 \\
1 \\
7\end{array}$ & $\begin{array}{c}35.22 \\
25.13 \\
0 \\
100\end{array}$ & $\begin{array}{l}.60 \\
.49 \\
0 \\
1\end{array}$ & $\begin{array}{l}.55 \\
.50 \\
0 \\
1\end{array}$ & $\begin{array}{c}2.46 \\
74 \\
1 \\
4\end{array}$ & $\begin{array}{c}4.44 \\
1.51 \\
1 \\
7\end{array}$ & $\begin{array}{c}3.2 \\
1.7 \\
1 \\
7\end{array}$ \\
\hline
\end{tabular}




\section{Results}

We were first interested in the associations between various social issues and feelings of status threat for White Americans and if such were conditioned by trust in conservative media outlets. Table 2 presents the OLS regression of social issues on status threat as well as the conditioning effects of conservative media on these associations. Model 1 aligns with what would be socially and politically [102] as well as empirically $[82,103]$ expected given the disparities in values and interests between conservatives and liberals. Model 1 reveals believing discrimination against Whites, illegal immigration, and climate change are important issues in the United States are significantly associated with feelings of status threat $(\beta=0.33,0.18$, and 0.06 , respectively). Furthermore, thinking the wealth gap and political correctness are problems are moderately, significantly positively associated with status threat ( $\beta=0.05$ and 0.05 , respectively). On the other hand, thinking discrimination against Blacks is an issue is significantly $(\beta=-0.23)$ and perceiving discrimination against women as a problem is moderately, significantly $(\beta=-0.06)$ associated with a decreased likelihood of feeling status threat for our sample of White Americans.

Table 2. OLS Regression of Perceptions of Social Issues on Status Threat.

\begin{tabular}{|c|c|c|c|c|c|c|}
\hline & \multicolumn{2}{|c|}{ Model 1} & \multicolumn{2}{|c|}{ Model 2} & \multicolumn{2}{|c|}{ Model 3} \\
\hline & $\beta$ & SE & $\beta$ & SE & $\beta$ & SE \\
\hline \multicolumn{7}{|l|}{ Perceived Social Problems with ... } \\
\hline Government Corruption & -0.02 & 0.03 & $<0.00$ & 0.03 & 0.05 & 0.05 \\
\hline Washington Elites & $<0.00$ & 0.03 & $<0.00$ & 0.03 & 0.01 & 0.05 \\
\hline Wealth Gap & $0.05^{\wedge}$ & 0.03 & $0.05^{\wedge}$ & 0.03 & 0.03 & 0.05 \\
\hline Discrimination Against Whites & $0.33^{* *}$ & 0.03 & $0.33^{* *}$ & 0.03 & $0.38 * *$ & 0.05 \\
\hline Discrimination Against Blacks & $-0.23 * *$ & 0.03 & $-0.22 * *$ & 0.03 & $-0.23 * *$ & 0.05 \\
\hline Political Correctness & $0.05^{\wedge}$ & 0.02 & 0.04 & 0.02 & 0.05 & 0.04 \\
\hline Discrimination Against Men & 0.01 & 0.03 & $<0.00$ & 0.03 & -0.05 & 0.05 \\
\hline Discrimination Against Women & $-0.06^{\wedge}$ & 0.03 & $-0.06^{*}$ & 0.03 & $-0.16^{* *}$ & 0.05 \\
\hline Illegal Immigration & $0.18 * *$ & 0.03 & $0.18 * *$ & 0.03 & $0.16^{* *}$ & 0.05 \\
\hline Islamic Terrorism & -0.01 & 0.03 & -0.02 & 0.03 & $-0.07^{\wedge}$ & 0.04 \\
\hline Crime & 0.04 & 0.03 & 0.03 & 0.03 & 0.02 & 0.05 \\
\hline Access to Healthcare & 0.03 & 0.03 & 0.03 & 0.03 & 0.08 & 0.05 \\
\hline Climate Change & $0.06 *$ & 0.02 & $0.08 * *$ & 0.02 & -0.05 & 0.04 \\
\hline Conservative Media & - & - & $0.10 * *$ & $>0.00$ & -0.12 & 0.01 \\
\hline Government Corruption X Media & - & - & - & - & -0.12 & $>0.00$ \\
\hline Washington Elites X Media & - & - & - & - & -0.06 & $>0.00$ \\
\hline Wealth Gap X Media & - & - & - & - & 0.04 & $>0.00$ \\
\hline Discrimination Against Whites X Media & - & - & - & - & -0.10 & $>0.00$ \\
\hline Discrimination Against Blacks X Media & - & - & - & - & 0.02 & $>0.00$ \\
\hline Political Correctness X Media & - & - & - & - & -0.07 & $>0.00$ \\
\hline Discrimination Against Men X Media & - & - & - & - & 0.11 & $>0.00$ \\
\hline Discrimination Against Women X Media & - & - & - & - & $0.16^{*}$ & $>0.00$ \\
\hline Illegal Immigration X Media & - & - & - & - & $<0.00$ & $>0.00$ \\
\hline Islamic Terrorism X Media & - & - & - & - & $0.19^{\wedge}$ & $>0.00$ \\
\hline Crime X Media & - & - & - & - & 0.04 & $>0.00$ \\
\hline Access to Healthcare X Media & - & - & - & - & -0.09 & $>0.00$ \\
\hline Climate Change X Media & - & - & - & - & $0.17 * *$ & $>0.00$ \\
\hline \multicolumn{7}{|l|}{ Controls } \\
\hline Gender & $0.04^{\wedge}$ & 0.08 & $0.04^{\wedge}$ & 0.08 & 0.03 & 0.08 \\
\hline Vote for Trump & 0.03 & 0.09 & 0.01 & 0.10 & $>0.00$ & 0.09 \\
\hline Financial Situation & $<0.00$ & 0.05 & $>0.00$ & 0.05 & 0.01 & 0.05 \\
\hline Friends Affiliated with the Alt-Right & 0.01 & 0.02 & 0.01 & 0.02 & 0.02 & 0.02 \\
\hline Social Dominance Orientation & $0.27 * *$ & 0.03 & $0.27 * *$ & 0.03 & $0.27 * *$ & 0.03 \\
\hline $\mathrm{F}$ & & $890.31 * *$ & & $870.27^{* *}$ & & $540.94 * *$ \\
\hline $\mathrm{R}^{2}$ & & 0.69 & & 0.69 & & 0.71 \\
\hline
\end{tabular}


Model 2 of Table 2 reveals trust in conservative media is significantly directly associated with an increased likelihood of perceiving status threat $(\beta=0.10)$. Additionally, Model 3 reveals conservative media does significantly condition some social issuesdiscrimination against women, climate change, and Islamic terrorism (modestly), in particular. Additional analyses were warranted, however, to decipher the meaning of these associations. The margins subcommand in Stata15 allows for the assessment of the multiplicative effects of trust in conservative media in conjunction with significant social issues on the likelihood of perceiving status threat. These conditioning effects are plotted in Figures 1-3 (full multiplicative effects available upon request). Surprisingly, Figures 1-3 reveal that trust in conservative media mitigates the associations between the perceptions of discrimination against women, climate change, and terrorism and the likelihood of perceiving status threat across the board. Of additional note, the models in Table 2 suggest perceptions of social issues and trust in conservative media, along with our controls, account for nearly $70 \%$ of the explained variance in feelings of status threat for White Americans $\left(R^{2}=0.69,0.69\right.$, and 0.71 , respectively).

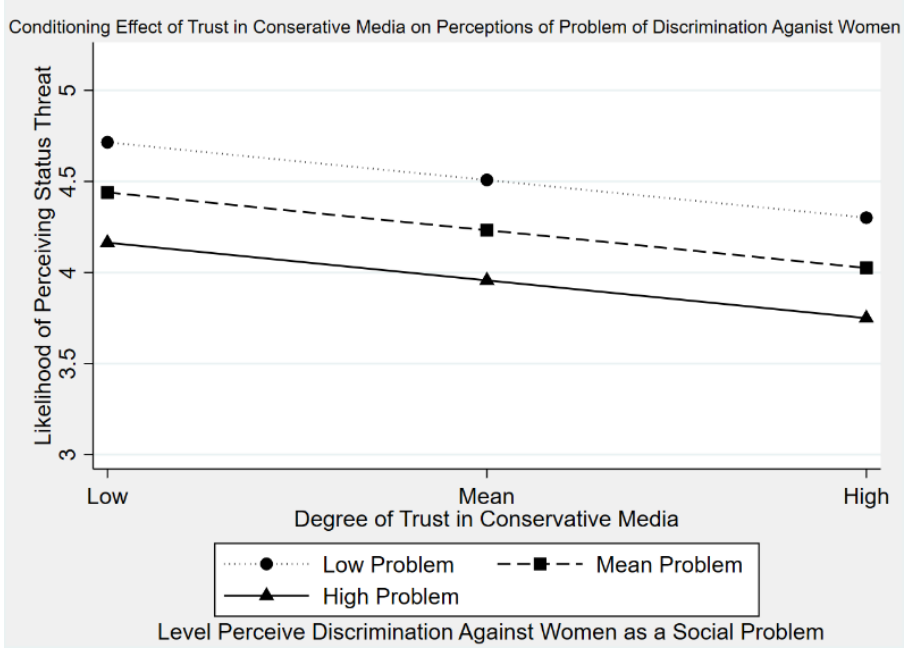

Figure 1. Conditioning Effect of Conservative Media: Discrimination against Women and Status Threat.

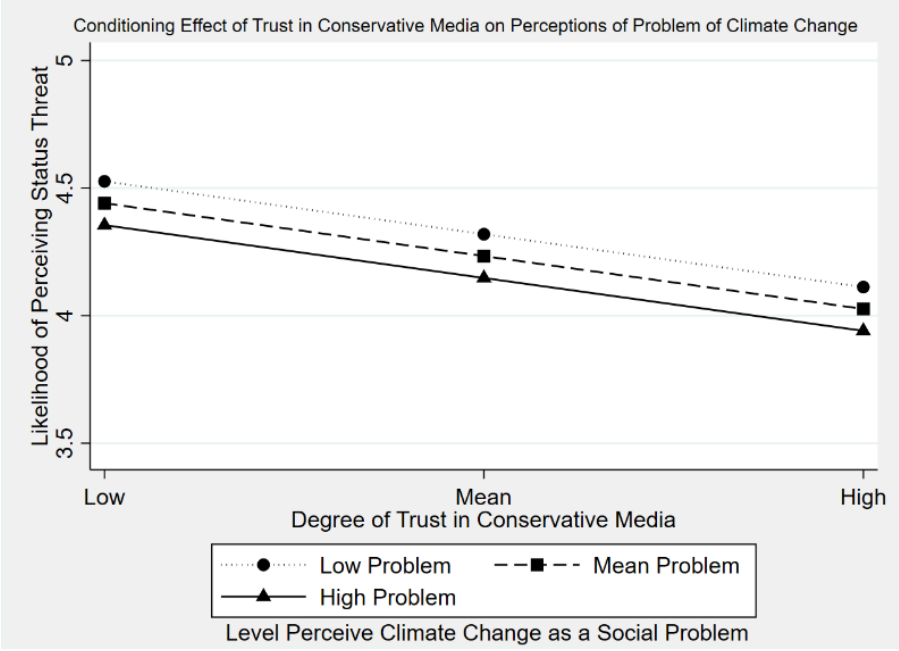

Figure 2. Conditioning Effect of Conservative Media: Climate Change and Status Threat. 


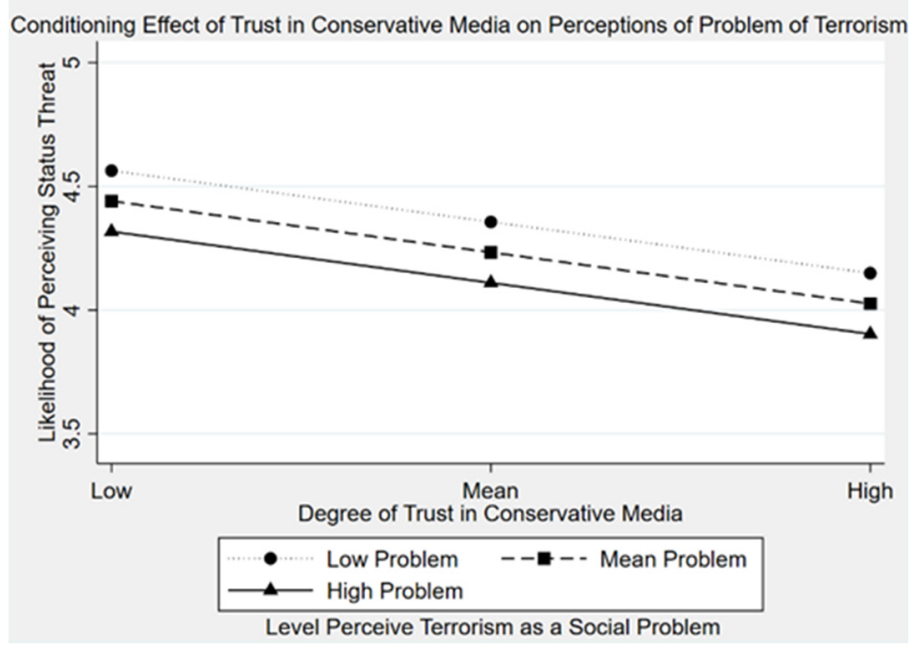

Figure 3. Conditioning Effect of Conservative Media: Terrorism and Status Threat.

Next, we were interested in the associations between perceived social issues and affiliation with the Alt-Right movement controlling for feelings of status threat and if trust in conservative media impacted these associations. Table 3 presents the binary logistic regressions of social issues on Alt-Right affiliation as well as the conditioning effects of conservative media. Similar to Table 2, there is a clear divide between traditionally conservative issues and liberal issues and affiliation with the Alt-Right. Model 1 reveals thinking discrimination against Whites and illegal immigration are important social problems are significantly associated with a greater odds of affiliating with the Alt-Right $(\mathrm{OR}=1.47$ and 1.19 , respectively). Furthermore, perceiving political correctness as an issue is moderately significantly associated with a greater odds of affiliating with the Alt-Right $(\mathrm{OR}=1.13)$. Additionally, on the other hand, thinking discrimination against Blacks and crime are significantly, and climate change is moderately significantly, associated with a decreased odds of Alt-Right affiliation (OR $=0.84,0.84$, and 0.87, respectively).

Model 2 of Table 3 reveals status threat is significantly directly associated with an increased odds of affiliation with the Alt-Right holding other factors constant $(\mathrm{OR}=1.38)$. Additionally, the significant associations of discrimination against Whites, crime, and climate change remain when status threat is included in the model. Model 3 finds trust in conservative media is not directly associated with Alt-Right affiliation. Yet, Model 4 reveals trust in conservative media does significantly condition the association between discrimination against Whites and Alt-Right affiliation as well as moderately significantly conditions the associations for government corruption and terrorism. These conditioning effects are plotted in Figures 4-6 (full multiplicative effects available upon request). Again, much like in relation to status threat, Figures 4-6 reveal trust in conservative media lessens the associations between perceptions of certain social issues and affiliation with the AltRight for our sample of White Americans.

In sum, concern over certain social issues, particularly those considered more conservative concerns (i.e., perceiving discrimination against Whites and illegal immigration), along with trust in conservative media explain a large portion of the variation in feelings of status threat among our sample of White Americans. Furthermore, social issues, particularly perceiving discrimination against Whites, illegal immigration, and political correctness, in addition to feelings of status threat, significantly increase the odds White Americans affiliate with the Alt-Right movement. Most surprisingly, however, trust in conservative media mitigated, instead of amplified, the associations between certain social issues and status threat as well as Alt-Right affiliation. 
Table 3. Logistic Regression of Perceptions of Social Issues on Affiliation with the Alt-Right.

\begin{tabular}{|c|c|c|c|c|c|c|c|c|}
\hline \multirow[b]{2}{*}{ Independent Variables } & \multicolumn{2}{|c|}{ Model 1} & \multicolumn{2}{|c|}{ Model 2} & \multicolumn{2}{|c|}{ Model 3} & \multicolumn{2}{|c|}{ Model 4} \\
\hline & OR & SE & OR & SE & OR & SE & OR & SE \\
\hline \multicolumn{9}{|l|}{ Perceived Social Problems with ... } \\
\hline Government Corruption & 0.99 & 0.09 & 1.01 & 0.09 & 1.02 & 0.09 & 0.81 & 0.14 \\
\hline Washington Elites & 0.96 & 0.08 & 0.97 & 0.08 & 0.97 & 0.08 & 1.11 & 0.19 \\
\hline Wealth Gap & 1.05 & 0.09 & 1.03 & 0.08 & 1.03 & 0.09 & 0.98 & 0.15 \\
\hline Discrimination Against Whites & $1.47 * *$ & 0.12 & $1.36^{* *}$ & 0.12 & $1.36^{* *}$ & 0.12 & $1.81 * *$ & 0.29 \\
\hline Discrimination Against Blacks & $0.84 *$ & 0.07 & 0.9 & 0.08 & 0.9 & 0.08 & 0.78 & 0.12 \\
\hline Political Correctness & $1.13^{\wedge}$ & 0.08 & 1.11 & 0.08 & 1.11 & 0.08 & $1.26^{\wedge}$ & 0.16 \\
\hline Discrimination Against Men & 1.04 & 0.08 & 1.05 & 0.08 & 1.04 & 0.08 & 0.87 & 0.13 \\
\hline Discrimination Against Women & 1.11 & 0.09 & 1.13 & 0.09 & 1.12 & 0.09 & 1.09 & 0.17 \\
\hline Illegal Immigration & $1.19^{*}$ & 0.1 & 1.14 & 0.1 & 1.14 & 0.1 & 1.17 & 0.18 \\
\hline Islamic Terrorism & 0.99 & 0.08 & 0.99 & 0.08 & 0.97 & 0.08 & 0.79 & 0.12 \\
\hline Crime & $0.84 *$ & 0.07 & $0.83 *$ & 0.07 & $0.83 *$ & 0.07 & 0.84 & 0.12 \\
\hline Access to Healthcare & 0.97 & 0.08 & 0.96 & 0.08 & 0.96 & 0.08 & 0.94 & 0.14 \\
\hline Climate Change & $0.87^{\wedge}$ & 0.06 & $0.85 *$ & 0.06 & $0.87 *$ & 0.06 & 0.91 & 0.12 \\
\hline Status Threat & - & - & $1.38^{* *}$ & 0.14 & $1.35^{* *}$ & 0.14 & $1.32 * *$ & 0.14 \\
\hline Conservative Media & - & - & - & - & 1.01 & 0.01 & 0.98 & 0.02 \\
\hline Government Corruption X Media & - & - & - & - & - & - & $1.01^{\wedge}$ & $>0.00$ \\
\hline Washington Elites X Media & - & - & - & - & - & - & 1 & $>0.00$ \\
\hline Wealth Gap X Media & - & - & - & - & - & - & 1 & $>0.00$ \\
\hline Discrimination Against Whites X Media & - & - & - & - & - & - & $0.99 *$ & $>0.00$ \\
\hline Discrimination Against Blacks X Media & - & - & - & - & - & - & 1 & $>0.00$ \\
\hline Political Correctness X Media & - & - & - & - & - & - & 1 & $>0.00$ \\
\hline Discrimination Against Men X Media & - & - & - & - & - & - & 1 & $>0.00$ \\
\hline Discrimination Against Women X Media & - & - & - & - & - & - & 1 & $>0.00$ \\
\hline Illegal Immigration X Media & - & - & - & - & - & - & 1 & $>0.00$ \\
\hline Islamic Terrorism X Media & - & - & - & - & - & - & $1.01^{\wedge}$ & $>0.00$ \\
\hline Crime X Media & - & - & - & - & - & - & 1 & $>0.00$ \\
\hline Access to Healthcare X Media & - & - & - & - & - & - & 1 & $>0.00$ \\
\hline \multirow{2}{*}{\multicolumn{9}{|c|}{ Controls }} \\
\hline & & & & & & & & \\
\hline Gender & 1.35 & 0.31 & 1.31 & 0.3 & 1.31 & 0.3 & 1.36 & 0.32 \\
\hline Vote for Trump & $3.03 * *$ & 0.72 & $2.98^{* *}$ & 0.71 & $2.79 * *$ & 0.68 & $2.73 * *$ & 0.68 \\
\hline Financial Situation & $0.62 * *$ & 0.1 & $0.62 * *$ & 0.1 & $0.64^{* *}$ & 0.1 & $0.63 * *$ & 0.1 \\
\hline Friends Affiliated with the Alt-Right & $0.66^{* *}$ & 0.05 & $0.65^{* *}$ & 0.05 & $0.65^{* *}$ & 0.05 & $0.65^{* *}$ & 0.05 \\
\hline Social Dominance Orientation & $1.27^{* *}$ & 0.12 & 1.16 & 0.11 & 1.16 & 0.11 & 1.17 & 0.11 \\
\hline Log Likelihood & & -296.39 & & -291.52 & & -290.73 & & -282.97 \\
\hline Likelihood Ratio $\chi^{2}$ & & $\underset{* *}{432.84}$ & & $\underset{* *}{442.58}$ & & $\underset{* *}{444.16}$ & & $459.68^{* *}$ \\
\hline
\end{tabular}

$p<0.10 ;{ }^{*} p<0.05 ;{ }^{* *} p<0.01$.

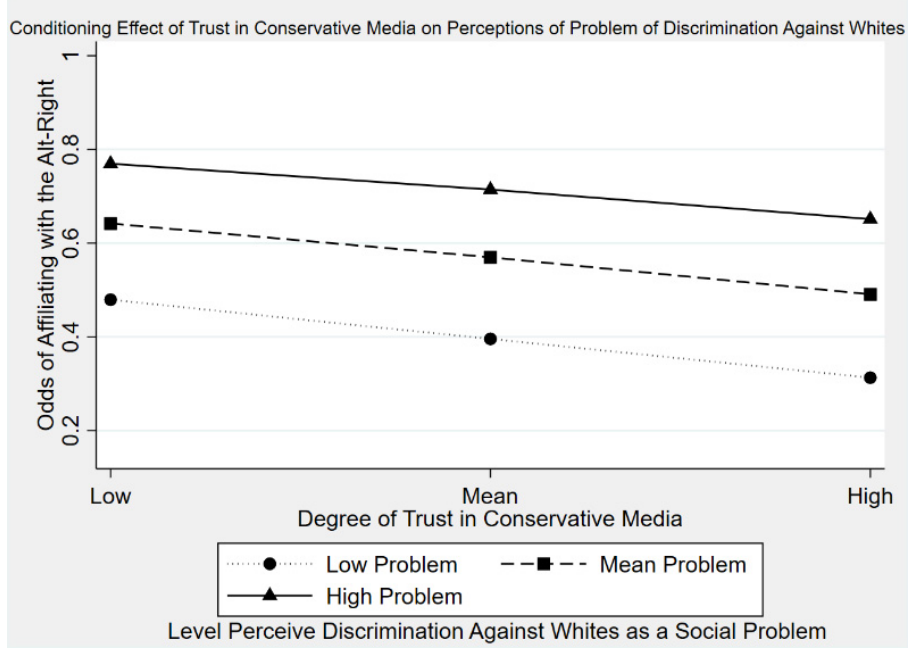

Figure 4. Conditioning Effect of Conservative Media: Discrimination against Women and the Alt-Right. 


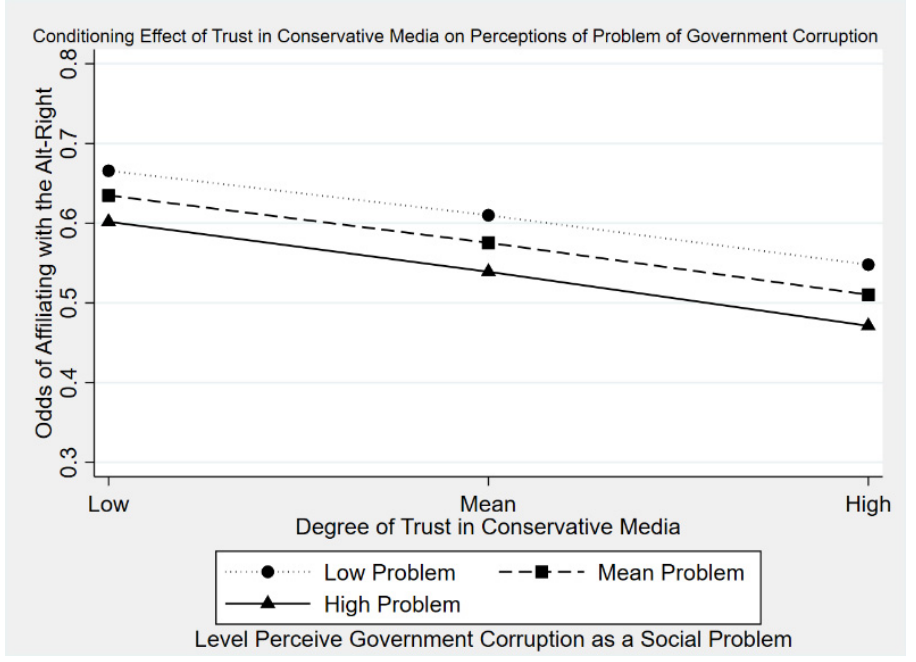

Figure 5. Conditioning Effect of Conservative Media: Government Corruption and the Alt-Right.

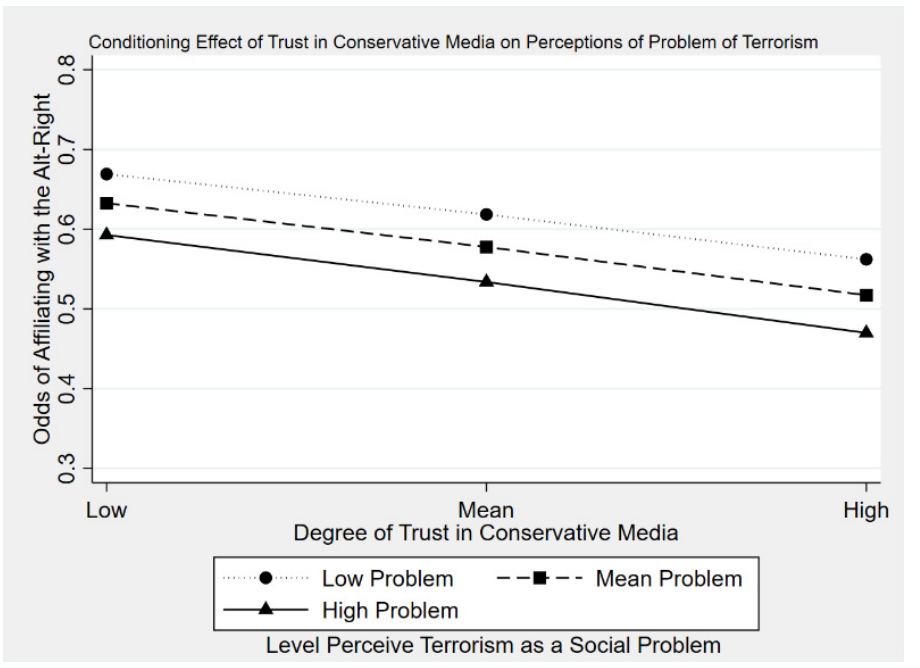

Figure 6. Conditioning Effect of Conservative Media: Terrorism and the Alt-Right.

\section{Discussion}

This study focuses on White Americans who choose to affiliate with the Alt-Right and the factors that influence such affiliation. We assessed the relationships between perceptions of social issues, feelings of status threat, trust in conservative media, and affiliation with the Alt-Right among White Americans. Our results support existing racialethnic and status threat hypotheses [33,37-40], revealing that illegal immigration, perceived discrimination against Whites, and political correctness are significant sources of status threat for White Americans. Furthermore, status threat from various social issues are significant factors in Alt-Right affiliation for White Americans. Additionally, our findings also suggest that media consumption and the assumption of factual and true information carry tremendous influence on White Americans' view of social issues. Specifically, Whites who trust in conservative media are more likely to perceive status threat. Though, trust in conservative media does not necessarily factor into White Americans' decisions to affiliate with the Alt-Right. Social issues such as discrimination against Blacks and women decrease the likelihood that White Americans may perceive threats to their status, which is also supported in other status threat literature.

Of overarching import, however, are our findings related to the media. The technology proclaimed to keep us informed and bring people together (i.e., social media and 24-h cable news), in reality fosters antagonism and division instead of substantive and respectful 
discourse [104]. No influencer has possibly capitalized on this social phenomenon more so than Donald Trump. His use of Twitter and other social media platforms, and the endless coverage of such by the political news channels, means he is the perpetual point of conversation, and the more provocative, the greater the coverage [105]. As a result, the more mainstream and left-leaning outlets criticize and counter Trump, the more emboldened his base becomes, reinforcing their distrust in less conservative news sources. Moreover, too many in the conservative audience take Trump and right-wing outlets at face value and are uncritical of the grandiloquence purported [106]. Furthermore, Trump granting extreme right-wing outlets, such as the Heritage Foundation and Claremont Institute, White House press passes and invitations to a social media summit, to the exclusion of Facebook and Twitter, further legitimized fringe political rhetoric [107,108]. For example, in July 2019 Trump attacked four freshman Democratic congresswomen of Color on Twitter saying they should "go back" to their home countries inciting chants of "send her back" from his supporters at a political rally a few days later [109]. Furthermore, Trump's rhetoric even prior to his loss to Joe Biden in the 2020 presidential election sparked the "\#StopTheSteal campaign" [110] which lead to the 6 January 2021 US Capitol riot [111-113].

Situating the media within incidents such as these provide context for the intricate results surrounding the role of conservative media found here. Given the divisive and inciteful nature of polarized media, it is rational to assume trust in conservative media would amplify the associations between social issues and status threat as well as affiliation with the Alt-Right. Yet, our analysis revealed the opposite- trust in conservative media mitigated the associations between social issues and status threat as well as Alt-Right affiliation. Recent qualitative findings [18] support the influence and polarization reinforced by conservative media. We purport our findings reflect the presence of a confounding factor-the larger online media environment that the Alt-Right originated in and spreads through.

The US has a particularly large and active right-wing digital news infrastructure, which has been associated with increasing distrust in traditional news media [114,115]. Within this broader architecture, the Alt-Right has an expansive online media environment encompassing a variety of platforms and content creators, including dedicated Alt-Right news sites, blogs, podcasts, YouTube videos, memes, and social media [115-121]. Furthermore, Alt-Right adjacent communities on YouTube, the Alt-Light, and Intellectual Dark Web, have served as entry points to the more extremist content of the movement [120,122]. These sources are further amplified through social media, allowing the movement to continue to grow and maintain visibility. Narratives on joining the Alt-Right most often reference this media environment rather than traditional conservative news $[116,118,120,123]$. Furthermore, research on the Alt-Right in Europe found that members are often distrustful of traditional media and rely on social media as their primary news source [123]. The central topics of this social media discourse include those social issues found here to be mitigated by trust in conservative media: discrimination against Whites, Islamic terrorism, government corruption, and climate change $[117,119]$. The mitigating effect of lower trust in conservative media may be explained by the Alt-Right's reliance on this online media environment rather than traditional conservative news sources, wherein specific social issues are emphasized resulting in the interaction effects observed here. These propositions align with the rise of anti-establishment perspectives more generally beyond the Alt-Right (e.g., anti-“normies" and QAnon believers) [81,124]. Our findings support the need for additional research into the intricate roles of media in varied forms and the rise of polarization and extremist beliefs in White America.

Our findings yield valuable insight into the complex and deep-rooted relationships between internalized and institutionalized racial hierarchies, concerns or social issues, and extremist ideologies for White Americans. Yet, as with all research, our study still has limitations, particularly due to the use of secondary data. For instance, while the data provided sound measures of a range of social issues, trust in conservative media, and perceptions of status threat, there were limited demographic variables collected by the 
original investigators [9]. Thus, we could not capture age, socioeconomic status (beyond perceptions of one's financial situation), marital status, region of the country, or religion, all known correlates of political ideology [96]. Relatedly, while beyond the present scope, the gendered nature of the assessed associations is worthy of future investigation. Our results revealed null or only moderately significant effects for gender (see Tables 2 and 3). However, extant research finds significant variation between White men and women in extremist beliefs and behaviors [20,125-127] as well as varied impacts of gender normative beliefs within similar contexts $[16,128]$. Future research should more deeply examine the variations between White men and women as well as the influence of internalized gender normative beliefs on similar associations as analyzed here.

Additionally, there are no indicators to address the role of the online media environment and its role in Alt-Right affiliation in the current data. Moreover, the sample is a convenience sample collected by MTurk. While shown to be a valuable research tool [89,91], online surveys generally still come with some issues such as sampling and recruitment of respondents, truthfulness, and access [92,129,130]. Future research should use other sampling strategies and methodologies to capture this hard-to-reach population to triangulate the results found here.

Furthermore, the data were collected shortly following the 2016 presidential election. A lot has happened in the United States since that time, including increased racial tensions around the 2020 US presidential election, particularly in the wake of the COVID-19 pandemic and the increased momentum of the Black Lives Matter movement. Given the almost daily racially charged events happening in recent history, we wonder if the present results would hold. To best capture these tumultuous times, more data collection is needed on a regular basis. Despite these limitations, our results build upon extant research and provide additional insight into the complexities of perceived threat, media consumption, and social issues for White Americans and their association with extreme conservative ideals.

\section{Conclusions}

Our country was founded on racial inequality, and white supremacy is firmly rooted in that history [5]. While political and racial tensions have ebbed and flowed over time, the 2016 presidential election sparked a degree of divisiveness unseen in America for decades. These divisions are being pushed to the brink in the wake of the controversies around the American response to the current global pandemic [131-133] and the rising support of criminal justice reform and racial justice spawning from the killings of George Floyd, Breonna Taylor, and Ahmaud Arbery, among numerous others [10]. While the majority of Americans support the movement [134], counter-protesters in the form of white supremacist groups, including All Lives Matter, Boogaloo Bois, and the Proud Boys, have made their enduring presence known [135]. Various media outlets have covered these protests differently, some applauding the social movement while others criticizing them as "riots" [136]. Understanding the role media plays in people's perceptions and responses to social issues are critical to finding ways to bridge the divide. The present work is an aid toward that aim.

Given extremism has infiltrated the mainstream, it is vital we understand what drives these extremist beliefs. The current FBI Director testified before Congress that white supremacy is the most "persistent, pervasive threat" to America today and the primary driver of modern domestic terrorism [137]. The 6 January 2021 insurrection at the US Capitol demonstrated the seriousness of this warning, as well as reinforced the vital role of the internet for right-wing extremism [138,139]. Unfortunately, as work such as this reveal, 'extreme' views are much more commonplace with the distance between white supremacist extremists and the 'average Joe' being shorter than most want to admit. Media is a primary player in shortening this distance. Until such is acknowledged in the narrative and addressed in the scholarship, the breadth and depth of this social phenomenon cannot be fully understood. We hope this is a call to action to continue to pursue understanding that can inform socially just change to heal our divided America. 
Author Contributions: Conceptualization, D.A.I., H.M.B., T.C.M., and M.R.; methodology, D.A.I., H.M.B., and M.R.; formal analysis, D.A.I.; resources, D.A.I., H.M.B., T.C.M., S.C. and M.R.; writingoriginal draft preparation, D.A.I., H.M.B., T.C.M. and M.R.; writing-review and editing, D.A.I., H.M.B., T.C.M. and S.C.; visualization, D.A.I. All authors have read and agreed to the published version of the manuscript.

Funding: This research received no external funding.

Institutional Review Board Statement: Not applicable.

Informed Consent Statement: Not applicable.

Data Availability Statement: Data retrieved from https:/ / osf.io/xge8q/ (accessed on 1 June 2021).

Conflicts of Interest: The authors declare no conflict of interest.

\section{References}

1. Crandall, C.S.; Miller, J.M.; White, M.H. Changing Norms Following the 2016 US Presidential Election: The Trump Effect on Prejudice. Soc. Psychol. Personal. Sci. 2018, 9, 186-192. [CrossRef]

2. United States. Department of Justice. 2017 Hate Crime Statistics; Federal Bureau of Investigation: Washington DC, USA, 2018. Available online: https:/ / ucr.fbi.gov / hate-crime/2017 (accessed on 15 September 2020).

3. Rosa, J.; Bonilla, Y. Deprovincializing Trump, Decolonizing Diversity, and Unsettling Anthropology. Am. Ethnol. 2017, 44, 201-208. [CrossRef]

4. Müller, K.; Schwarz, C. From Hashtag to Hate Crime: Twitter and Anti-Minority Sentiment. SSRN Electron. J. 2020. [CrossRef]

5. Anderson, C. White Rage: The Unspoken Truth of Our Racial Divide; Bloomsbury Publishing: New York, NY, USA, 2016.

6. Barkun, M. President Trump and the "Fringe". Terror. Political Violence 2017, 29, 437-443. [CrossRef]

7. Bernhardt, D.; Krasa, S.; Polborn, M. Political Polarization and the Electoral Effects of Media Bias. J. Public Econ. 2008, 92, 1092-1104. [CrossRef]

8. Mutz, D.C. How the Mass Media Divide Us. Red Blue Nation 2007, 1, 223-248.

9. Forscher, P.S.; Kteily, N.S. A Psychological Profile of the Alt-Right. Perspect. Psychol. Sci. 2020, 15, 90-116. Available online: https: / / osf.io/xge8q/ (accessed on 1 May 2020). [CrossRef]

10. Kirby, J. “Black Lives Matter" Has Become a Global Rallying Cry against Racism and Police Brutality. Vox, 7 June 2020. Available online: https:/ / www.vox.com/2020/6/12/21285244/black-lives-matter-global-protests-george-floyd-uk-belgium (accessed on 10 June 2020).

11. Somvichian-Clausen, A. What the 2020 Black Lives Matter Protests Have Achieved So Far. Hill Chang. Am. 2020. Available online: https:/ / thehill.com/changing-america/respect/equality/502121-what-the-2020-black-lives-matter-protests-haveachieved-so (accessed on 13 March 2021).

12. Mezzofiore, G.; Polglase, K. White Supremacists Openly Organize Racial Violence on Telegram, Report Finds. Cable News Netw. 2020. Available online: https://www.cnn.com/2020/06/26/tech/white-supremacists-telegram-racism-intl/index.html (accessed on 28 September 2020).

13. Hochschild, A.R. Strangers in Their Own Land: Anger and Mourning on the American Right; The New Press: New York, NY, USA, 2018.

14. Wuthnow, R. The Left Behind: Decline and Rage in Small-Town America; Princeton University Press: Princeton, NJ, USA, 2019.

15. Goetz, S.J.; Partridge, M.D.; Stephens, H.M. The Economic Status of Rural America in the President Trump Era and Beyond. Appl. Econ. Perspect. Policy 2018, 40, 97-118. [CrossRef]

16. Boehme, H.M.; Isom Scott, D.A. Alt-White? A Gendered Look at "Victim" Ideology and the Alt-Right. Vict. Offenders 2020, 15, 174-196. [CrossRef]

17. Ferber, A.L. White Man Falling: Race, Gender, and White Supremacy; Rowman \& Littlefield Publishers: Washington, DC, USA, 1998.

18. Isom, D.A.; Mikell, T.C.; Boehme, H.M. White America, Threat to the Status Quo, and Affiliation with the Alt-Right: A Qualitative Approach. Sociol. Spectr. 2021, 41, 213-228. [CrossRef]

19. Isom Scott, D.A. Understanding White Americans' perceptions of "reverse" discrimination: An application of a new theory of status dissonance. In Advances in Group Processes; Thye, S.R., Lawler, E.J., Eds.; Emerald Publishing Limited: Bingley, UK, 2018; Volume 35, pp. 129-157.

20. Kimmel, M. Angry White Men: American Masculinity at the End of an Era; Bold Type Books: New York, NY, USA, 2017.

21. Outten, H.R.; Schmitt, M.T.; Miller, D.A.; Garcia, A.L. Feeling Threatened about the Future: Whites' Emotional Reactions to Anticipated Ethnic Demographic Changes. Personal. Soc. Psychol. Bull. 2012, 38, 14-25. [CrossRef]

22. Willer, R.; Feinberg, M.; Wetts, R. Threats to Racial Status Promote Tea Party Support among White Americans. SSRN Electron. J. 2016. [CrossRef]

23. Gorski, P. Why evangelicals voted for trump: A critical cultural sociology. In Politics of Meaning/Meaning of Politics; Mast, J.L., Alexander, J.C., Eds.; Springer: New York, NY, USA, 2019; pp. 165-183. 
24. Mutz, D.C. Status Threat, Not Economic Hardship, Explains the 2016 Presidential Vote. Proc. Natl. Acad. Sci. USA 2018, 115, E4330-E4339. [CrossRef]

25. Andaya, E. "I'm Building a Wall around My Uterus": Abortion Politics and the Politics of Othering in Trump's America. Cult. Anthropol. 2019, 34, 10-17. [CrossRef]

26. Jones, T. Trump, Trans Students and Transnational Progress. Sex Educ. 2018, 18, 479-494. [CrossRef]

27. Hooghe, M.; Dassonneville, R. Explaining the Trump Vote: The Effect of Racist Resentment and Anti-Immigrant Sentiments. PS Political Sci. Politics 2018, 51, 528-534. [CrossRef]

28. Sides, J.; Tesler, M.; Vavreck, L. Hunting Where the Ducks Are: Activating Support for Donald Trump in the 2016 Republican Primary. J. Elect. Public Opin. Parties 2018, 28, 135-156. [CrossRef]

29. Alexander, M. The New Jim Crow: Mass Incarceration in the Age of Colorblindness; The New Press: New York, NY, USA, 2010.

30. Butler, P. Chokehold: Policing Black Men; The New Press: New York, NY, USA, 2017.

31. Wise, T. Dear White America: Letter to a New Minority; City Lights Publishers: San Francisco, CA, USA, 2012.

32. Bobo, L.D. Whites' Opposition to Busing: Symbolic Racism or Realistic Group Conflict? J. Personal. Soc. Psychol. 1983, 45, 1196-1210. [CrossRef]

33. Tajfel, H.; Turner, J.C. An integrative theory of inter-group conflict. In The Social Psychology of Inter-Group Relations; Austin, W.G., Worchel, S., Eds.; Brooks/Cole: Monterey, CA, USA, 1979; pp. 33-47.

34. Goffman, E. The Presentation of Self in Everyday Life; Anchor Books: New York, NY, USA, 1959.

35. Mead, G.H. Mind, Self, and Society from the Standpoint of a Social Behaviorist; The University of Chicago Press: Chicago, IL, USA, 1934.

36. Hewston, M.; Rubin, M.; Willis, H. Intergroup Bias. Annu. Rev. Psychol. 2002, 53, 575-604. [CrossRef] [PubMed]

37. Blalock, H.M. Toward a Theory of Minority-Group Relations; Macmillan: New York, NY, USA, 1967.

38. Blumer, H. Race Prejudice as a Sense of Group Position. Pac. Sociol. Rev. 1958, 1, 3-7. [CrossRef]

39. Bobo, L.; Hutchings, V.L. Perceptions of Racial Group Competition: Extending Blumer's Theory of Group Position to a Multiracial Social Context. Am. Sociol. Rev. 1996, 61, 951-972. [CrossRef]

40. Bobo, L.D. Prejudice as Group Position: Microfoundations of a Sociological Approach to Racism and Race Relations. J. Soc. Issues 1999, 55, 445-472. [CrossRef]

41. Craig, M.A.; Richeson, J.A. On the Precipice of a "Majority-Minority" America: Perceived Status Threat from the Racial Demographic Shift Affects White Americans' Political Ideology. Psychol. Sci. 2014, 25, 1189-1197. [CrossRef]

42. Liska, A.E. (Ed.) Social Threat and Social Control; SUNY Press: Albany, NY, USA, 1992.

43. Stults, B.J.; Baumer, E.P. Racial Context and Police Force Size: Evaluating the Empirical Validity of the Minority Threat Perspective. Am. J. Sociol. 2007, 113, 507-546. [CrossRef]

44. Eitle, D.; D'Alessio, S.J.; Stolzenberg, L. Racial Threat and Social Control: A Test of the Political, Economic, and Threat of Black Crime Hypotheses. Soc. Forces 2002, 81, 557-576. [CrossRef]

45. Parker, K.F.; Stults, B.J.; Rice, S.K. Racial Threat, Concentrated Disadvantage and Social Control: Considering the Macro-Level Sources of Variation in Arrests. Criminology 2005, 43, 1111-1134. [CrossRef]

46. Keen, B.; Jacobs, D. Racial Threat, Partisan Politics, and Racial Disparities in Prison Admissions: A Panel Analysis. Criminology 2009, 47, 209-238. [CrossRef]

47. Myers, M.A. Black Threat and Incarceration in Postbellum Georgia. Soc. Forces 1990, 69, 373-393. [CrossRef]

48. Crawford, C.; Chiricos, T.; Kleck, G. Race, Racial Threat, and Sentencing of Habitual Offenders. Criminology 1998, 36, 481-512. [CrossRef]

49. Crow, M.S.; Johnson, K.A. Race, Ethnicity, and Habitual-Offender Sentencing: A Multilevel Analysis of Individual and Contextual Threat. Crim. Justice Policy Rev. 2008, 19, 63-83. [CrossRef]

50. Chiricos, T.; Welch, K.; Gertz, M. Racial Typification of Crime and Support for Punitive Measures. Criminology 2004, 42, 358-390. [CrossRef]

51. Welch, K.; Payne, A.A.; Chiricos, T.; Gertz, M. The Typification of Hispanics as Criminals and Support for Punitive Crime Control Policies. Soc. Sci. Res. 2011, 40, 822-840. [CrossRef]

52. Feldmeyer, B.; Warren, P.Y.; Siennick, S.E.; Neptune, M. Racial, Ethnic, and Immigrant Threat: Is There a New Criminal Threat on State Sentencing? J. Res. Crime Delinq. 2015, 52, 62-92. [CrossRef]

53. Wang, X.; Mears, D.P. A Multilevel Test of Minority Threat Effects on Sentencing. J. Quant. Criminol. 2010, 26, 191-215. [CrossRef]

54. Morrison, K.R.; Fast, N.J.; Ybarra, O. Group Status, Perceptions of Threat, and Support for Social Inequality. J. Exp. Soc. Psychol. 2009, 45, 204-210. [CrossRef]

55. Umphress, E.E.; Smith-Crowe, K.; Brief, A.P.; Dietz, J.; Watkins, M.B. When Birds of a Feather Flock Together and When They Do Not: Status Composition, Social Dominance Orientation, and Organizational Attractiveness. J. Appl. Psychol. 2007, 92, 396-409. [CrossRef]

56. Garimella, K.; De Francisci Morales, G.; Gionis, A.; Mathioudakis, M. Political Discourse on Social Media: Echo Chambers, Gatekeepers, and the Price of Bipartisanship. In Proceedings of the 2018 World Wide Web Conference, Lyon, France, 23-27 April 2018; International World Wide Web Conferences Steering Committee: Geneva, Switzerland, 2018; pp. 913-922.

57. Phua, J.J. Sports Fans and Media Use: Influence on Sports Fan Identification and Collective Self-Esteem. Int. J. Sport Commun. 2010, 3, 190-206. [CrossRef] 
58. Lee, C.J. The Interplay between Media Use and Interpersonal Communication in the Context of Healthy Lifestyle Behaviors: Reinforcing or Substituting? Mass Commun. Soc. 2009, 13, 48-66. [CrossRef] [PubMed]

59. Wilson, J.D.; MacGillivray, M.S. Self-Perceived Influences of Family, Friends, and Media on Adolescent Clothing Choice. Fam. Consum. Sci. Res. J. 1998, 26, 425-443. [CrossRef]

60. Newton, K. May the Weak Force Be with You: The Power of the Mass Media in Modern Politics. Eur. J. Political Res. 2006, 45, 209-234. [CrossRef]

61. Messing, S.; Westwood, S.J. Selective Exposure in the Age of Social Media: Endorsements Trump Partisan Source Affiliation When Selecting News Online. Commun. Res. 2014, 41, 1042-1063. [CrossRef]

62. Martin, G.J.; Yurukoglu, A. Bias in Cable News: Persuasion and Polarization. Am. Econ. Rev. 2017, 107, 2565-2599. [CrossRef]

63. Bode, L. Political News in the News Feed: Learning Politics from Social Media. Mass Commun. Soc. 2016, 19, 24-48. [CrossRef]

64. Allcott, H.; Gentzkow, M. Social Media and Fake News in the 2016 Election. J. Econ. Perspect. 2017, 31, 211-236. [CrossRef]

65. Boxell, L.; Gentzkow, M.; Shapiro, J.M. Is the Internet Causing Political Polarization? Evidence from Demographics (No. w23258); National Bureau of Economic Research: Cambridge, MA, USA, 2017. Available online: https://www.nber.org/system/files/ working_papers/w23258/w23258.pdf (accessed on 26 March 2021).

66. DellaVigna, S.; Kaplan, E. The Fox News Effect: Media Bias and Voting. Q. J. Econ. 2007, 122, 1187-1234. [CrossRef]

67. Auletta, K. Vox Fox: How Roger Ailes and Fox News are changing cable news. New Yorker 2003, 26, 1187-1234.

68. Collins, S. Crazy Like a FOX: The Inside Story of How Fox News Beat CNN; Penguin: New York, NY, USA, 2004.

69. Morris, J.S. The Fox News Factor. Harv. Int. J. Press/Politics 2005, 10, 56-79. [CrossRef]

70. Gallagher, T. The Outsider on the Inside: Donald Trump's Twitter Activity and the Rhetoric of Separation from Washington Culture. Atl. J. Commun. 2019, 27, 183-189. [CrossRef]

71. Gallagher, T. Trump TV: The Trump Campaign's Real News Update as Competitor to Cable News. Vis. Commun. Q. 2019, 26, 32-43. [CrossRef]

72. Yglesias, M. The Case for Fox News Studies. Political Commun. 2018, 35, 681-683. [CrossRef]

73. Pickard, V. Media Failures in the Age of Trump. Political Econ. Commun. 2017, 4, 118-122.

74. Burkhardt, J.M. History of Fake News. Libr. Technol. Rep. 2017, 53, 5-9.

75. Polletta, F.; Callahan, J. Deep stories, nostalgia narratives, and fake news: Storytelling in the trump era. In Politics of Meaning/Meaning of Politics; Mast, J.L., Alexander, J.C., Eds.; Springer: New York, NY, USA, 2019; pp. 55-73.

76. Persily, N. The 2016 US Election: Can Democracy Survive the Internet? J. Democr. 2017, 28, 63-76. [CrossRef]

77. Southern Poverty Law Center. Alt-Right. Available online: https://www.splcenter.org/fighting-hate/extremist-files/ideology/ alt-right (accessed on 25 October 2018).

78. Daniels, J. The Algorithmic Rise of the "Alt-Right". Contexts 2018, 17, 60-65. [CrossRef]

79. Johnson, J. The Self-Radicalization of White Men: "Fake News" and the Affective Networking of Paranoia. Commun. Cult. Crit. 2018, 11, 100-115. [CrossRef]

80. Kelly, A. The Alt-Right: Reactionary Rehabilitation for White Masculinity. Soundings 2017, 66, 68-78. [CrossRef]

81. Nagle, A. Kill All Normies: Online Culture Wars from 4chan and Tumblr to Trump and the Alt-Right; John Hunt Publishing: London, UK, 2017.

82. Iyengar, S.; Hahn, K.S. Red Media, Blue Media: Evidence of Ideological Selectivity in Media Use. J. Commun. 2009, 59, 19-39. [CrossRef]

83. Rosenberg, H.; Feldman, C.S. No Time to Think: The Menace of Media Speed and the 24-Hour News Cycle; A\&C Black: London, UK, 2008.

84. Ash, E.; Morelli, M.; Van Weelden, R. Elections and Divisiveness: Theory and Evidence. J. Politics 2017, 79, 1268-1285. [CrossRef]

85. Olzak, S. The Dynamics of Ethnic Competition and Conflict; Stanford University Press: Stanford, CA, USA, 1992.

86. Isom Scott, D.A.; Andersen, T.S. 'Whitelash?' Status Threat, Anger, and White America: A General Strain Theory Approach. J. Crime Justice 2020, 43, 414-432. [CrossRef]

87. Jardina, A. White Identity Politics; Cambridge University Press: Cambridge, UK, 2019.

88. Klein, E. Why We're Polarized; Profile Books: London, UK, 2020.

89. Landers, R.N.; Behrend, T.S. An Inconvenient Truth: Arbitrary Distinctions between Organizational, Mechanical Turk, and Other Convenience Samples. Ind. Organ. Psychol. 2015, 8, 142-164. [CrossRef]

90. Hauser, D.J.; Schwarz, N. Attentive Turkers: MTurk Participants Perform Better on Online Attention Checks than Do Subject Pool Participants. Behav. Res. Methods 2016, 48, 400-407. [CrossRef]

91. Smith, N.A.; Sabat, I.E.; Martinez, L.R.; Weaver, K.; Xu, S. A Convenient Solution: Using MTurk to Sample from Hard-To-Reach Populations. Ind. Organ. Psychol. 2015, 8, 220-228. [CrossRef]

92. Chandler, J.J.; Paolacci, G. Lie for a Dime: When Most Prescreening Responses are Honest but Most Study Participants are Impostors. Soc. Psychol. Personal. Sci. 2017, 8, 500-508. [CrossRef]

93. Levay, K.E.; Freese, J.; Druckman, J.N. The Demographic and Political Composition of Mechanical Turk Samples. Sage Open 2016, 6. [CrossRef]

94. Faris, R.; Roberts, H.; Etling, B.; Bourassa, N.; Zuckerman, E.; Benkler, Y. Partisanship, Propaganda, and Disinformation: Online Media and the 2016 US Presidential Election. Berkman Klein Cent. Res. Publ. 2017, 6. Available online: http://nrs.harvard.edu/ urn-3:HUL.InstRepos:33759251 (accessed on 1 April 2021). 
95. Marwick, A.; Lewis, R. Media Manipulation and Disinformation Online; Data \& Society Research Institute: New York, NY, USA, 2017. Available online: https:/ / datasociety.net/library/media-manipulation-and-disinfo-online/ (accessed on 1 April 2021).

96. Jost, J.T.; Federico, C.M.; Napier, J.L. Political Ideology: Its Structure, Functions, and Elective Affinities. Annu. Rev. Psychol. 2009, 60, 307-337. [CrossRef] [PubMed]

97. Dey, E.L. Undergraduate Political Attitudes: Peer Influence in Changing Social Contexts. J. High. Educ. 1997, 68, 398-413. [CrossRef]

98. Pratto, F.; Sidanius, J.; Stallworth, L.M.; Malle, B.F. Social Dominance Orientation: A Personality Variable Predicting Social and Political Attitudes. J. Personal. Soc. Psychol. 1994, 67, 741-763. [CrossRef]

99. Hiel, A.V.; Mervielde, I. Explaining Conservative Beliefs and Political Preferences: A Comparison of Social Dominance Orientation and Authoritarianism. J. Appl. Soc. Psychol. 2002, 32, 965-976. [CrossRef]

100. Roccato, M.; Ricolfi, L. On the Correlation between Right-Wing Authoritarianism and Social Dominance Orientation. Basic Appl. Soc. Psychol. 2005, 27, 187-200. [CrossRef]

101. Ho, A.K.; Sidanius, J.; Kteily, N.; Sheehy-Skeffington, J.; Pratto, F.; Henkel, K.E.; Foels, R.; Stewart, A.L. The Nature of Social Dominance Orientation: Theorizing and Measuring Preferences for Intergroup Inequality Using the New SDO 7 Scale. J. Pers. Soc. Psychol. 2015, 109, 1003-1028. [CrossRef] [PubMed]

102. McCandless, D.; Posavec, S. Left vs. Right (US). December 2010. Available online: https://informationisbeautiful.net/ visualizations / left-vs-right-us / (accessed on 29 July 2019).

103. Crawford, J.T.; Brandt, M.J.; Inbar, Y.; Chambers, J.R.; Motyl, M. Social and Economic Ideologies Differentially Predict Prejudice across the Political Spectrum, but Social Issues are Most Divisive. J. Personal. Soc. Psychol. 2017, 112, 383-412. [CrossRef] [PubMed]

104. Vaidhyanathan, S. Antisocial Media: How Facebook Disconnects Us and Undermines Democracy; Oxford University Press: New York, NY, USA, 2018.

105. Zelizer, J. Trump is a Dangerous Media Mastermind. CNN, 21 July 2019. Available online: https://www.cnn.com/2019/07/21 /opinions/trump-racist-tweet-mastery-media-coverage-zelizer/index.html (accessed on 1 April 2021).

106. Peters, J.W. Michael Savage Has Doubts About Trump. His Conservative Radio Audience Does Not. The New York Times, 18 June 2019. Available online: https://www.nytimes.com/2019/06/18/us/politics/michael-savage-trump.html (accessed on 1 April 2021).

107. Darcy, O. Trump Invites Right-Wing Extremists to White House 'Social Media Summit'. CNN, 11 July 2019. Available online: https:/ / www.cnn.com/2019/07/10/tech/white-house-social-media-summit/index.html (accessed on 1 April 2021).

108. Rosenwald, B. Trump Just Launched the Newest Phase of the GOP's Romance with Right-Wing Media. The Washington Post, 13 July 2019. Available online: https:/ / www.washingtonpost.com/outlook/2019/07/13/trump-just-launched-newest-phase-gopsromance-with-right-wing-media/?utm_term=.92ec6eea1f48 (accessed on 18 September 2020).

109. Rummler, O. Trump Supporters Echo His Racist Tweets, Chanting 'Send Her Back'. Axios. 17 July 2019. Available online: https: / / www.axios.com/trump-supporters-chant-send-her-back-rally-echoing-racist-tweets-274f0261-f69b-4755-906d3da7f06582fb.html (accessed on 1 June 2021).

110. Holt, J. \#StopTheSteal: Timeline of Social Media and Extremist Activities Leading to 1/6 Insurrection. Just Security, 10 February 2021. Available online: https:// www.justsecurity.org/74622/stopthesteal-timeline-of-social-media-and-extremist-activitiesleading-to-1-6-insurrection/ (accessed on 1 April 2021).

111. Hauck, G.; Barfield Barry, D. ‘Double Standard': Biden, Black Lawmakers and Activists Decry Police Response to Attack on US Capitol. USA Today, 13 January 2021. Available online: https://www.usatoday.com/story/news/nation/2021/01/06/us-capitolattack-compared-response-black-lives-matter-protests/6570528002/ (accessed on 1 April 2021).

112. Hymes, C.; McDonald, C.; Watson, E. What We Know About the "Unprecedented" U.S. Capitol Riot Arrests. CBS News, 16 April 2021. Available online: https:/ /www.cbsnews.com/news/capitol-riot-arrests-2021-04-16/ (accessed on 1 April 2021).

113. Stein, R.; Willis, H.; Miller, D.; Schmidt, M.S.U.S. Capitol Riot. The New York Times, 22 March 2021. Available online: https: //www.nytimes.com/spotlight/us-capitol-riots-investigations (accessed on 1 April 2021).

114. Heft, A.; Mayerhöffer, E.; Reinhardt, S.; Knüpfer, C. Beyond Breitbart: Right-Wing Digital News Infrastructures in Six Western Democracies. Policy Internet 2019, 12, 20-45. [CrossRef]

115. Main, T.J. The Rise of the Alt-Right; Brookings Institution Press: Washington, DC, USA, 2018.

116. Boatman, E. The Kids are Alt-Right: How Media and the Law Enable White Supremacist Groups to Recruit and Radicalize Emotionally Vulnerable Individuals. Law J. Soc. Justice 2019, 12, 2-61. [CrossRef]

117. Gallaher, C. Mainstreaming White Supremacy: A Twitter Analysis of the American 'Alt-Right'. J. Fem. Geogr. 2021, 28, $224-252$. [CrossRef]

118. Lorenzo-Dus, N.; Nouri, L. The Discourse of the US Alt-Right Online-A Case Study of the Traditionalist Worker Party Blog. Crit. Discourse Stud. 2020. [CrossRef]

119. Panizo-Lledot, A.; Torregrosa, J.; Bello-Orgaz, G.; Thorburn, J.; Camacho, D. Describing Alt-Right Communities and Their Discourse on Twitter during the 2018 US Mid-term Elections. In Complex Networks 2019: Complex Networks and Their Applications VIII; Cherifi, H., Gaito, S., Mendes, J., Moro, E., Rocha, L., Eds.; Springer: New York, NY, USA, 2020; Volume 882, pp. $427-439$.

120. Munn, L. Alt-Right Pipeline: Individual Journeys to Extremism Online. First Monday 2019, 24. [CrossRef] 
121. Torregrosa, J.; Panizo-Lledot, Á.; Bello-Orgaz, G.; Camacho, D. Analyzing the Relationship between Relevance and Extremist Discourse in an Alt-Right Network on Twitter. Soc. Netw. Anal. Min. 2020, 10. [CrossRef]

122. Ribeiro, M.H.; Ottoni, R.; West, R.; Almeida, V.A.F.; Meira, W. Auditing radicalization pathways on YouTube. In Proceedings of the 2020 Conference on Fairness, Accountability, and Transparency; ACM Digital Library, 2020. Available online: https://dl.acm.org/doi/ abs/10.1145/3351095.3372879 (accessed on 1 July 2021).

123. Schulze, H. Who Uses Right-Wing Alternative Online Media? An Exploration of Audience Characteristics. Politics Gov. 2020, 8, 6-18. [CrossRef]

124. De Zeeuw, D.; Hagen, S.; Peeters, S.; Jokubauskaite, E. Tracing Normiefication: A Cross-Platform Analysis of the QAnon Conspiracy Theory. First Monday 2020, 25. [CrossRef]

125. Blee, K.M. Inside Organized Racism: Women in the Hate Movement; University of California Press: Oakland, CA, USA, 2002.

126. Jones-Rogers, S.E. They Were Her Property: White Women as Slave Owners in the American South; Yale University Press: Princeton, NJ, USA, 2019.

127. Ferber, A.L. Constructing Whiteness: The Intersections of Race and Gender in US White Supremacist Discourse. Ethn. Racial Stud. 1998, 21, 48-63. [CrossRef]

128. Isom, D.A.; Boehme, H.M.; Cann, D.; Wilson, A. The White Right: A Gendered Look at the Links between 'Victim' Ideology and Anti-Black Lives Matter Sentiments in the Era of Trump. Crit. Sociol.. in press.

129. Riggle, E.D.; Rostosky, S.S.; Reedy, C.S. Online Surveys for BGLT Research: Issues and Techniques. J. Homosex. 2005, 49, 1-21. [CrossRef] [PubMed]

130. Wessl, K.S.; Huber, J.; Netzer, O. Mturk Character Misrepresentation: Assessment and Solutions. J. Consum. Res. 2017, 44, 211-230.

131. Bosman, J.; Tavernise, S.; Baker, M. Why These Protesters Aren't Staying Home for Coronavirus Orders. The New York Times, 23 April 2020. Available online: https:/ / www.nytimes.com/2020/04/23/us/coronavirus-protesters.html (accessed on 18 September 2020).

132. Riess, R. Protesters in Michigan Demonstrate Against Stay-At-Home Order. CNN, 20 April 2020. Available online: https://www. cnn.com/us/live-news/us-coronavirus-update-04-30-20/h_e90047bd263620ce7d71d643aba02ed0 (accessed on 18 September 2020).

133. Warren, M.; Marquez, M.; Scannell, K.; Perez, E. Conservative groups boost anti-stay-at-home protests. CNN, 20 April 2020. Available online: https://www.cnn.com/2020/04/20/politics/stay-at-home-protests-conservative-groups-support/index.html (accessed on 18 September 2020).

134. Russonello, G. Why Most Americans Support the Protests. The New York Times, 5 June 2020. Available online: https://www. nytimes.com/2020/06/05/us/politics/polling-george-floyd-protests-racism.html (accessed on 18 September 2020).

135. Anti-Defamation League. Small but Vocal Array of Right Wing Extremists Appearing at Protests. June 2020. Available online: https:/ / www.adl.org/blog/small-but-vocal-array-of-right-wing-extremists-appearing-at-protests (accessed on 1 April 2020).

136. Kilgo, D. Riot or Resistance? The Way the Media Frames the Unrest in Minneapolis Will Shape the Public's View of Protest. Nieman Foundation: Harvard University, May 2020. Available online: https://www.niemanlab.org/2020/05/riot-or-resistancethe-way-the-media-frames-the-unrest-in-minneapolis-will-shape-the-publics-view-of-protest/?relatedstory (accessed on 20 April 2020).

137. Papenfuss, M. FBI Chief Christopher Wray Warns of 'Persistent, Pervasive' White Supremacy Threat. Huffpost, 4 April 2019. Available online: https:/ / www.huffpost.com/entry/fbi-christopher-wray-white-supremacy-pervasive-threat_n_5ca68631e4 b0dca032fed83f (accessed on 18 September 2020).

138. Estes, A.C.; How Neo-Nazis Used the Internet to Instigate a Right-Wing Extremist Crisis. Vox, 2 February 2021. Available online: https: / / www.vox.com/recode/22256387/ facebook-telegram-qanon-proud-boys-alt-right-hate-groups (accessed on 1 April 2021).

139. Romano, A. Baked Alaska's Clout-Chasing Spiral into White Supremacy is an Internet Morality Tale. Vox, 17 January 2021. Available online: https://www.vox.com/22235691/baked-alaska-tim-gionet-arrest-capitol-riot-alt-right-buzzfeed (accessed on 1 April 2021). 